been recorded in man up to now. Guidelines for the use of nuclear magnetic resonance in Britain are available from the National Radiation Protection Board. ${ }^{15}$ The theoretical hazards of induction of cardiac fibrillation and cerebral dysrhythmia by currents from rapid magnetic field changes seem remote under present operating conditions. More information is required, however, and people with epilepsy and cardiac disease are not suitable as volunteers. ${ }^{15}$ Heating of metal prostheses by radiofrequency-induced electrical fields is another potential hazard.

Nuclear magnetic resonance imaging has advanced rapidly in a short time. The immediate prospect is of its clinical application as a technique complementary to CT scanning. In the middle distance, provided that costs can be contained and development proceeds apace, it is likely to supersede CT scanning in several diagnostic areas. Over the horizon, the possibility of marrying other nuclear magnetic resonance techniques, such as spectroscopy with imaging, could render less than fanciful the notion of precisely identifying, localising, and monitoring the physiological, metabolic, and pathological features of tissues in vivo, with negligible hazard to the patient. Before the turn of the century?

Consultant Neurologist,

Midland Centre for Neurosurgery and Neurology,

Smethwick, Warley,

West Midlands B67 7JX
${ }^{1}$ Hounsfield GN. Computerised transverse axial scanning (tomography) 1. Description of system. Br $\mathcal{F}$ Radiol $1973 ; 46: 1016-22$.

2 Kreel L. Diagnostic imaging: introduction. Br Med Bull 1980;36:205-8. ్ㅡ

${ }^{3}$ Doyle FH, Gore JC, Pennock JM, et al. Imaging of the brain by nuclear magnetic resonance. Lancet 1981 ;ii:53-7.

+ Edelstein WA, Hutchison JMS, Smith FW, Mallard J, Johnson G, ำ Redpath JW. Human whole body NMR tomographic imaging: normal sections. Br $\mathcal{F}$ Radiol $1981 ; 54: 149-51$.

5 Hawkes RC, Holland GN, Moore WS, Worthington BS. Nuclear magnetic $\overline{\bar{D}}$ resonance $(N M R)$ tomography of the brain: a preliminary clinical $D$ assessment with demonstration of pathology. F Comput Assist Tomogr $\mathbb{D}$ $1980 ; 4: 577-86$.

${ }^{6}$ Holland GN, Hawkes RC, Moore WS. Nuclear magnetic resonance $\varrho$ (NMR) tomography of the brain : coronal and sagittal sections. $\mathcal{f}$ Comput Assist Tomogr 1980;4:429-33.

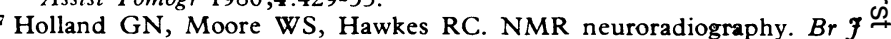
Radiol $1980 ; 53: 253-5$.

${ }^{8}$ Holland GN, Moore WS, Hawkes RC. Nuclear magnetic resonance $\frac{\bar{\sigma}}{\sigma}$ tomography of the brain. F Comput Assist Tomogr 1980;4:1-3.

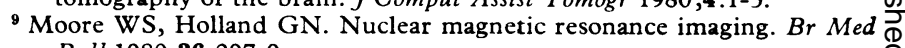
Bull 1980;36:297-9.

10 Moore WS, Holland GN, Kreel L. The NMR CAT scanner: a new look at the brain. CT 1980;4:1-7.

11 Young IR, Burl M, Clarke CJ, et al. Magnetic resonance properties of $\vec{\circ}$ hydrogen: imaging the posterior fossa. AfR $1981 ; 137: 895-901$.

12 Young IR, Hall AS, Pallis CA, Legg NJ, Bydder GM, Steiner RE. $\vec{\omega}$ Nuclear magnetic resonance imaging of the brain in multiple sclerosis. Lancet 1981 ;ii: $1063-6$.

13 Smith FW, Hutchison JMS, Mallard JR, et al. Oesophageal carcinoma demonstrated by whole-body nuclear magnetic resonance imaging. $N$ Br Med f 1981 ;282:510-2.

14 Budinger TF. Nuclear magnetic resonance (NMR) in vivo studies: known ö thresholds for health effects. F Comput Assist Tomogr 1981;5:800-11.

15 Nuclear Radiation Protection Board. Exposure to nuclear magnetic resonance. clinical imaging. Harwell, Oxon: NRPB, 1980.

\title{
Alcohol: clearing the decks for action
}

In the past year we have devoted a great deal of our space to alcohol problems. Daily these are becoming worse; thinking on them has changed dramatically in the past decade; but the response of the Government to them has remained inadequate and uninspired.

The consumption of alcohol has doubled in the past 20 years in Britain, ${ }^{1}$ and as a direct result every form of alcohol damage that can be measured has increased greatly as well. The range of damage is frighteningly wide-affecting individuals' bodies and minds, families, and the social and economic life of every community. ${ }^{1}$ Individual health and social workers have recently been bombarded with information on alcohol problems and are beginning to respond. The Health Education Council and the Scottish Health Education Group are stepping up their alcohol education campaigns. Sadly, however, until now the response by the voluntary organisations and the Government has been poor, but the recent report by a Department of Health and Social Security study group on the voluntary organisations concerned with alcohol abuse ${ }^{2}$ ( $p$ 1392) may usher in a new era.

The report is strongly critical of the existing voluntary organisations, all of which receive money from the department - that is, the National Council on Alcoholism, the Medical Council on Alcoholism, the Alcohol Education Centre, and the Federation of Alcoholic Rehabilitation Establishments. It suggests that they should be disbanded with a new organisation being created to do the work of all four. Mr Kenneth Clarke, the new Minister of Health, has called for reactions to the report by the end of June. The weakness, rivalry, and overlap of work of the four have long been recognised by those concerned with alcohol problems, and we welcome the idea of a new organisation that will allow a new start as well as a rationalisation of the work. The report makes further suggestions, which we also support: that the medical royal colleges should do more to educate doctors on alcohol problems, and that they should set up a new pressure group-a kind of alcohol equivalent to Action on Smoking and Health. $\stackrel{2}{\Rightarrow}$ Discussions have been going on for over a year on forming this $\frac{O}{3}$ campaigning organisation, and the time certainly seems ripe for it to be born.

We need such a group because the Government continues to be equivocal in its response to alcohol problems. The drink trade is rich and powerful and supplies the Government with:much needed revenue, jobs, and exports ( $p$ 1392). The 3 . Government is thus understandably unwilling to take strongo action to reduce alcohol consumption, but if we are to have fewer alcohol problems then we as a nation must drink less, 음 and the Government should adopt policies to ensure that this $N$ happens. The much discussed Central Policy Review Staff $>$ (the "think-tank") report of 1979 suggested a coherent policy․ㅡ․ for the Government, but the report has never been published. N Instead, we have been given the much criticised Drinking N Sensibly. ${ }^{3}$ We join with the British Fournal of Addiction ${ }^{4}$ in advocating publication of that "think-tank" report, which wee at the $B M \mathcal{F}$ have seen and admired. As a matter of urgency the Government should take up the policies that this report ${ }^{+}$ suggests, and in particular it should establish an interdepart- $\frac{0}{0}$ mental committee and forge a coherent policy on alcohol.

1 Special Committee of the Royal College of Psychiatrists. Alcohol and alcoholism. London: Tavistock Publications, 1979.

2 Department of Health and Social Security. National voluntary organisations and alcohol misuse. London: DHSS, 1982.

${ }^{3}$ Department of Health and Social Security. Prevention and health: drinking sensibly. London: HMSO, 1981.

4 Anonymous. Public interest. Br $\mathcal{F}$ Addict 1982;77:1-2. 